\title{
Effects of within-group homogeneity of physiological state on individual feeding behaviour of loose-housed Charolais cows
}

\author{
Stéphane INGRAND ${ }^{\mathrm{a} *}$, Jacques AGABRIEL ${ }^{\mathrm{b}}$, Benoît DEDIEU ${ }^{\mathrm{a}}$, \\ Jacques LASSALAS ${ }^{\text {b }}$ \\ a Unité de Recherches sur les Herbivores, Départements SAD et ENA, \\ Institut National de la Recherche Agronomique, 63122 Saint-Genès-Champanelle, France \\ ${ }^{\mathrm{b}}$ Département ENA, Unité de Recherches sur les Herbivores, \\ Institut National de la Recherche Agronomique, 63122 Saint-Genès-Champanelle, France
}

(Received 26 May 1999; accepted 29 November 1999)

\begin{abstract}
The criteria used by farmers to assign animals to the different groups do not only concern nutritional aspects, implying that each group is not homogeneous with regards to nutrient requirements. The food intake and feeding behaviour of 12 loose-housed Charolais cows (6 dry and 6 lactating), given hay ad libitum were compared in homogeneous (Hom) and heterogeneous (Het) groups according to their physiological states: Hom groups were comprised of cows in similar physiological states (dry or lactating) and Het groups were comprised of cows in different physiological states (dry + lactating). No difference was detected in daily intake level in Hom and Het groups: 14.8 and $14.5 \mathrm{~kg}$ DM for dry cows, 15.4 and 15.3 for lactating cows, respectively, nor for daily time of eating: $4 \mathrm{~h} 53$ and $4 \mathrm{~h} 44$ for dry cows, $5 \mathrm{~h} 50$ and $5 \mathrm{~h} 34$ for lactating cows. In Het groups, lactating cows ate more at night: from midnight to 10.00 hours, they had already spent $2 \mathrm{~h}$ eating vs. $1 \mathrm{~h} 30 \mathrm{in}$ Hom groups. Cows had significantly more short meals $(<1 \mathrm{~h})$ in Het groups: $11.1 \mathrm{vs.} 9.0$ for dry cows and 12.4 vs. 10.6 for lactating cows in Het and Hom groups, respectively. This fractionising of the eating activity concerned particularly submissive dry cows and high producing lactating cows.
\end{abstract}

Beef cow / food intake / feeding behaviour / group feeding

Résumé - Effets de l'homogénéité intra-lot des stades physiologiques sur le comportement alimentaire de vaches Charolaises conduites en stabulation libre. Les critères utilisés par les éleveurs pour constituer les différents lots de vaches dans les troupeaux allaitants ne concernent pas toujours les aspects nutritionnels. Des animaux présentant des besoins nutritionnels différents sont souvent conduits ensemble, ce qui pose la question du risque d'altération des performances individuelles. Le niveau d'ingestion et le comportement alimentaire de 12 vaches Charolaises ( 6 taries et 6 en

* Correspondence and reprints

Tel.: +33 (0)4 736242 91; fax : +33 (0)4 736241 18; e-mail: ingrand@ clermont.inra.fr 
lactation), conduites en stabulation libre et nourries au foin à volonté ont été comparés selon qu'elles sont conduites en lots homogènes (Hom) ou hétérogènes (Het) sur le plan du stade physiologique (i.e. des besoins nutritionnels). Les 4 lots Hom ( $n=3$ vaches) étaient constitués soit de vaches taries (VT), soit de vaches en lactation (VL) et les 2 lots Het ( $n=6$ vaches), de 3 vaches taries +3 vaches en lactation (VT + VL). Le niveau d'ingestion du lot Hom a été équivalent à celui du lot Het : respectivement 14,8 et 14,5 $\mathrm{kg}$ MS pour les VT et 15,4 et 15,3 kg MS pour les VL, ainsi que la durée quotidienne d'ingestion : respectivement 4 h 53 et 4 h 44 pour les VT, 5 h 50 et 5 h 34 pour les VL. Les vaches en lactation ont davantage ingéré la nuit dans les lots Het que dans les lots Hom : respectivement $2 \mathrm{~h}$ et $1 \mathrm{~h} 30$ d'ingestion cumulée entre minuit et $10 \mathrm{~h}$ du matin ( ${ }^{\text {ère }}$ distribution de foin). Les vaches ont effectué significativement plus de petits repas quotidiens $(<1 \mathrm{~h})$ dans les lots Het que dans les lots Hom : 11,1 vs. 9,0 respectivement pour les VT et 12,4 vs. 10,6 respectivement pour les VL. Ce fractionnement de l'activité d'ingestion a été le plus important pour les VT dominées et pour les VL à niveau de production laitière élevé.

vache allaitante / niveau d'ingestion / comportement alimentaire / alimentation en groupe

\section{INTRODUCTION}

The feeding recommendations used for beef cows are applicable to the average animal in a specified group [8], assuming the group is as homogeneous as possible with regards to individual nutrient requirements. On commercial farms, beef herds are increasingly large, and to simplify management, farmers mainly make fewer modifications of groups in the herds. Furthermore, the criteria used by farmers to assign animals to the different groups do not only concern nutritional aspects. This implies that each group is not homogeneous, especially with regards to nutrient requirements [15].

There are some interactions between cows managed in a group, such as social hierarchy, with dominant and submissive animals, or such as social facilitation for moving or for eating $[2,26,27]$. For loosehoused dairy cows, the high level of variability of individual intake cannot always be explained by milk yield [23]. However, the variability of the rate of intake is greater for high producing cows [19]. For multiparous dairy cows, milk yield is positively correlated to meal size and to the duration of the feeding bouts, but it is not correlated to the rate of intake [6, 7]. The aim of this work was to compare, without competition for food, the intake level and feeding behaviour of dry and lactating beef cows (two levels of nutrient requirements), managed in two situations with regards to group composition: cows in the same physiological state (either dry or lactating cows) and cows in mixed physiological states (dry + lactating). The hypothesis is that dry cows synchronise their eating activity with lactating cows and tend to eat more and for a longer time [26, 27].

\section{MATERIALS AND METHODS}

\subsection{Animals, feed, measurements}

Two groups of six cows were included in a trial conducted at the Laqueuille experimental farm (Inra, Puy-de-Dôme, France) during the winter 96/97. Each group was composed of 3 dry and 3 lactating cows. The cows were loose-housed (slatted floor beside the mangers and straw bedding for the resting area): one group in a pen (pen 1) equipped with an electronic system to record individual data for intake level and feeding behaviour, and the other group in a standard non-equipped pen (pen 2), which only allowed the average daily intake to be assessed for the group. Each group (6 cows per group) was composed as follows: a homogeneous physiological state (Hom) where the group was divided into 2 sub-groups 
$(n=3)$ according to physiological state (dry or lactating), and a heterogeneous physiological state (Het) where the 6 cows were managed together. Two treatments were applied in turn to each group of six cows for 3 weeks. The group size (3 vs. 6) was assumed to have no effect [29]. The dry and lactating cows were assigned to the two groups according to their body weight, calving date, body condition score and hierarchical rank measured during a pre-experimental period. The same density was provided in all situations by using a barrier to divide pens for the Hom groups. The trial had a cross-over design with four periods using the 2 groups of cows in the 2 pens; the total duration of the trial, including a pre-experimental period, was 14 weeks (Tab. I). All the cows were offered feed ad libitum with natural grass hay (10 to $15 \%$ refusal), at two daily meals (10.00 and 16.00 hours). They had free access to water. Samples of hay $(500 \mathrm{~g})$ were taken twice weekly and dried at $80{ }^{\circ} \mathrm{C}$ to estimate dry matter (DM) concentration for hay offered and refused. The dry matter digestibility was $58.3 \%$, measured using sheep. Chemical analyses were also performed to evaluate organic matter content $(93.1 \%)$, crude protein (134 g/kg DM) and crude fibre (306 g/kg DM). From these values, equations were used to calculate the energy content $(5.0 \mathrm{MJ} / \mathrm{kg} \mathrm{DM})$ and the filling value for cattle (1.06) [17].

In pen 2, offered and refused amounts of hay were weighed respectively from Monday to Thursday and from Tuesday to Friday. Hence four daily data points per week were available for the average intake level in the group. In pen 1, individual food intake and feeding behaviour was monitored automatically with an electronic system named "Solot" [14], similar to systems used for dairy cattle $[3,8]$. The hay was placed in mangers automatically weighed by compression type load cells. Each access (one per manger) was fitted with a loop to energise the transponder of any cow feeding in the manger. The corresponding identity of the cow was transmitted to a microcomputer and a file appended with the time, the cow's identity, and the number and the weight of the manger. If any cow-day data were incomplete for any time during a day (computer malfunction or human error), they were omitted from the analysis.

The cows were videotaped $24 \mathrm{~h}$ a day over periods of 5 days for each trial to estimate the social rank of each cow, and to determine feeding behaviour in pen 2 (time, duration and frequency of meals).

The cows were weighed monthly. Body size was assessed by measuring height at withers, chest depth, and width at trochanter with a measuring stick. Body condition was scored monthly from 0 to 5 [1]. Average body condition score of the cows when assigned to the groups were 2.4 and 2.1 for dry and lactating cows, respectively. Calves were allowed access to their mothers twice daily at 07.30 and 16.30 hours, for about 15 to 20 min each time. Milk production of lactating cows was estimated weekly by weighing calves before and after suckling [22]. Social hierarchy for feeding was assessed in Het groups by viewing the video tapes: rank 1 for the two most dominant cows, rank 2 for the two intermediate cows and rank 3 for the two most submissive cows. There was a straight-line rank-order in the two groups. Average body weight was $782 \mathrm{~kg}$ and $694 \mathrm{~kg}$ respectively for dry and lactating cows, with respective ranges of 702 to $890 \mathrm{~kg}$ and 630 to $752 \mathrm{~kg}$. Despite the difference in body weight between dry and lactating cows $(88 \mathrm{~kg})$, the net energy requirements of the latter were still twice those of the former. The dry cows were significantly higher ranked $(P<0.01)$ in each group compared with their lactating counterparts, probably because of the difference in body weight.

\subsection{Data analysis}

Dependent variables in the analyses were daily intake level and variables describing 
feeding behaviour: individual daily time of eating, individual daily rate of eating, number of meals, synchronisation of eating activity and daily pattern of eating. The daily rate of eating was calculated by dividing daily intake level by daily time of eating. Meals were determined with a 5 min interval criterion (to account for differences between intra- and inter-meal intervals). The synchronisation of eating activities was assessed by calculating the number of cows eating at the same time [30]. A value of synchronisation was calculated for each cow, taking into account all the meals available throughout the trial: if the cow always ate alone, the value would be 1 ; if the cow always ate with all her counterparts, this value would be 6 (group size). The 24-hour period was divided into 3 parts: from 07.00 to 15.00 hours, from 15.00 to 23.00 hours and from 23.00 to 07.00 hours. Long and short meals were distinguished according to duration: more or less than 1 hour. The daily pattern of time spent eating per hour was also analysed.

The effects of the treatments (Hom and Het) were analysed on the average for the group and individually for each cow in the group. In the first case, a SAS Mixed model procedure [28] was performed to analyse the effect of treatments of groups, according to the physiological state of cows. By using a SAS Mixed procedure, individual measurements were used for cows kept in the group, assuming the interactions between individuals were the same whatever the animal. The fixed effects included in the model were the physiological state (dry or lactating), the period (Tab. I), and the treatment (Hom or Het). The cow within the group was included as a random effect. The values of intake level assessed in pen 2 (average for the group) were weighed according to the number of animals in the group ( $n=3$ for Hom and $n=6$ for Het). Some comparisons of means, using the Duncan's method, were performed to compare Hom and Het treatments for each physiological state. The daily pattern of eating for each treatment (time of eating per hour) were compared by using the Kolmogorov-Smirnov test.

In the second case, the cows were clustered according to the differences in feeding behaviour between the two treatments for the following variables (value in Hom minus value in Het): intake level, eating time, number of long and short meals, synchronisation of eating activity. It combined a principal component analysis (PCA) and a cluster analysis using principal component scores [21]. The clusters were then described and compared (SAS GLM), using the characteristics of cows (physiological state, size, body weight, body condition, milk production level, social rank).

\section{RESULTS}

\subsection{Relationships between variables of feeding}

Individual variables concerning intake level and feeding behaviour were averaged for the trial according to each treatment. The relationships between these variables were more often significant for the Hom treatment (Tab. II). The only two relationships which were significant in the two treatments firstly concerned the daily time of eating and rate of eating and secondly, the number of long meals and rate of eating. With the Hom treatment, intake level was positively correlated with the number of short meals $(r=0.69)$ and with the rate of eating $(r=0.66)$, and negatively correlated with the number of long meals $(r=-0.73)$. The number of short meals was negatively correlated with the number of long meals $(r=-0.61)$.

On the contrary, some correlations involving daily time of eating were significant only in the Het treatment group: time spent eating was positively correlated with intake level, number of short meals and number of long meals. In the Het treatment, no relationship was detected between rate of eating and intake level. 
Table I. Description of the trial involving 2 groups of 6 Charolais cows ( 3 dry and 3 lactating cows in each group, mixed together or separated with a barrier), permuting in 2 pens (pen 1, equipped for individual data assessment of intake level; pen 2, standard pen). The data assessed during the pre-experimental and the transition periods were not used for the analyses.

\begin{tabular}{lccc}
\hline Period & Duration & \multicolumn{2}{c}{ Physiological states } \\
\cline { 3 - 4 } & & Group 1 $(n=6)$ & Group 2 $(n=6)$ \\
\hline Pre-experimental & 1 week & Mixed & Separated \\
1 & 3 weeks & Mixed & Separated \\
2 & 3 weeks & Separated & Mixed \\
Transition & 1 week & Mixed & Separated \\
3 & 3 weeks & Mixed & Separated \\
4 & 3 weeks & Meparated & Mixed \\
\hline
\end{tabular}

Table II. Correlation matrix for variables of feeding behaviour ${ }^{1}$ (average values for the 12 cows when placed in pen 1; see Fig. 1).

\begin{tabular}{lrccc}
\hline & \multicolumn{1}{c}{ DIL $^{2}$} & DTE & NSM & NLM \\
\hline Daily time of eating (DTE) & $-0.02 / 0.54$ & & & \\
No. short meals (NSM) & $\mathbf{0 . 6 9} / 0.27$ & $0.18 / 0.58$ & & \\
No. long meals (NLM) & $-\mathbf{0 . 7 3} / 0.28$ & $0.39 / 0.55$ & $-0.61 /-0.04$ & \\
& & & & \\
Rate of eating & $\mathbf{0 . 6 6} / 0.00$ & $\mathbf{- 0 . 7 5} / \mathbf{- 0 . 8 2}$ & $0.30 /-0.47$ & $\mathbf{- 0 . 7 8} /-0.50$
\end{tabular}

${ }^{1}$ bold numbers are statistically significant, $P<0.01$.

${ }^{2}$ DIL: daily intake level.

\subsection{Dry vs. lactating cows: intake, time and rate of eating}

The average daily intake level for the two replicates was $14.6 \mathrm{~kg}$ DM for dry cows (ranging from 12.3 to 15.8 ) and $15.4 \mathrm{~kg}$ for lactating cows (ranging from 12.3 to 17.3 ) $(P<0.05)$. According to body weight, the corresponding values ranged from 1.08 to $2.11 \mathrm{~kg} / 100 \mathrm{~kg} \mathrm{BW}$ for dry cows (average: 1.68) and from 1.61 to $2.34 \mathrm{~kg} / 100 \mathrm{~kg} \mathrm{BW}$ for lactating cows (average: 2.02). The daily time of eating was significantly greater (one hour more) for lactating cows: 342 vs. 289 min for dry cows. The dry cows ate sig- nificantly faster than the lactating cows: 51 vs. $45 \mathrm{~g} / \mathrm{min}$, because of their higher body weights.

\subsection{Similar vs. different physiological states in the group (Tab. III)}

The daily intake level was not significantly different between the Hom and Het groups, with respectively 14.9 and $15.1 \mathrm{~kg}$ of eaten DM. No difference appeared for dry cows nor for lactating cows between Hom and Het groups. The average daily time of eating was $315 \mathrm{~min}$ and tended to be greater in Het groups for both physiological states, 
Table III. Comparison of intake and feeding behaviour of dry and lactating cows in homogeneous (Hom) and heterogeneous (Het) groups.

\begin{tabular}{|c|c|c|c|c|c|c|c|c|c|}
\hline \multirow{3}{*}{$\begin{array}{l}\text { Treatment } \\
\text { Number of cows }\end{array}$} & \multicolumn{3}{|c|}{ Dry cows } & \multicolumn{3}{|c|}{ Lactating cows } & \multicolumn{3}{|c|}{ Total } \\
\hline & Hom & Het & Stat. & Hom & Het & Stat. & Hom & Het & Stat. \\
\hline & 12 & 12 & & 12 & 12 & & 24 & 24 & \\
\hline \multicolumn{10}{|l|}{$24 \mathrm{~h}$ period } \\
\hline Intake level (kg DM/cow/day) & $14.5 \pm 0.26$ & $14.8 \pm 0.30$ & & $15.3 \pm 0.40$ & $15.4 \pm 0.27$ & & $14.9 \pm 0.25$ & $15.1 \pm 0.20$ & \\
\hline Time spent eating ( $\mathrm{min} /$ day) & $284 \pm 13.4$ & $293 \pm 10.5$ & & $334 \pm 9.7$ & $350 \pm 10.4$ & & $309 \pm 9.6$ & $321 \pm 9.3$ & \\
\hline Rate of eating (g DM/min) & $52 \pm 2.9$ & $51 \pm 2.17$ & & $46 \pm 1.6$ & $44 \pm 1.1$ & & $49 \pm 1.8$ & $48 \pm 1.4$ & \\
\hline Number of short meals (/day $)^{1}$ & $7.7 \pm 0.64$ & $10.4 \pm 0.58$ & $* *$ & $9.3 \pm 0.62$ & $11.1 \pm 0.51$ & * & $8.5 \pm 0.47$ & $10.8 \pm 0.38$ & $* * *$ \\
\hline Number of long meals (/day) $)^{1}$ & $1.3 \pm 0.30$ & $0.7 \pm 0.20$ & & $1.3 \pm 0.20$ & $1.3 \pm 0.12$ & & $1.3 \pm 0.18$ & $1.0 \pm 0.13$ & \\
\hline Total number of meals (/day) & $9.0 \pm 0.47$ & $11.1 \pm 0.46$ & $* *$ & $10.6 \pm 0.58$ & $12.4 \pm 0.49$ & $*$ & $9.8 \pm 0.40$ & $11.8 \pm 0.35$ & $* * *$ \\
\hline Synchronisation of eating activity ${ }^{2}$ & $2.8 \pm 0.05$ & $2.9 \pm 0.03$ & & $2.8 \pm 0.04$ & $2.7 \pm 0.03$ & & $2.8 \pm 0.03$ & $2.8 \pm 0.03$ & \\
\hline \multicolumn{10}{|l|}{ from 7 ' to $15^{\prime}$} \\
\hline Number of short meals ${ }^{1}$ & $3.2 \pm 0.35$ & $3.9 \pm 0.33$ & & $3.7 \pm 0.27$ & $4.1 \pm 0.37$ & & $3.4 \pm 0.22$ & $4.0 \pm 0.24$ & \\
\hline Duration of short meals (min) & $20 \pm 2.2$ & $23 \pm 1.1$ & & $22 \pm 1.0$ & $24 \pm 1.5$ & & $21 \pm 1.2$ & $24 \pm 0.9$ & \\
\hline Number of long meals ${ }^{1}$ & $0.5 \pm 0.17$ & $0.4 \pm 0.15$ & & $0.7 \pm 0.11$ & $0.7 \pm 0.11$ & & $0.6 \pm 0.10$ & $0.5 \pm 0.10$ & \\
\hline Duration of long meals (min) & $86 \pm 3.1$ & $81 \pm 6.2$ & & $83 \pm 4.1$ & $85 \pm 4.0$ & & $84 \pm 2.6$ & $83 \pm 3.6$ & \\
\hline \multicolumn{10}{|l|}{ from $15^{\prime}$ to $23^{\prime}$} \\
\hline Number of short meals ${ }^{1}$ & $3.3 \pm 0.31$ & $4.4 \pm 0.28$ & $* *$ & $3.7 \pm 0.31$ & $4.3 \pm 0.21$ & & $3.5 \pm 0.22$ & $4.4 \pm 0.17$ & $* *$ \\
\hline Duration of short meals (min) & $26 \pm 1.1$ & $23 \pm 0.8$ & $*$ & $24 \pm 1.3$ & $23 \pm 0.8$ & & $25 \pm: 0.9$ & $23 \pm 0.6$ & \\
\hline Number of long meals ${ }^{1}$ & $0.5 \pm 0.10$ & $0.3 \pm 0.05$ & $*$ & $0.6 \pm 0.10$ & $0.4 \pm 0.07$ & & $0.5 \pm 0.07$ & $0.3 \pm 0.04$ & $* *$ \\
\hline Duration of long meals (min) & $81 \pm 3.0$ & $77 \pm 3.4$ & & $81 \pm 1.9$ & $84 \pm 4.2$ & & $81 \pm 1.7$ & $80 \pm 2.7$ & \\
\hline \multicolumn{10}{|l|}{ from $23^{\prime}$ to 7} \\
\hline Number of short meals ${ }^{1}$ & $1.3 \pm 0.24$ & $2.1 \pm 0.14$ & $* *$ & $1.8 \pm 0.22$ & $2.7 \pm 0.23$ & $* *$ & $1.5 \pm 0.17$ & $2.4 \pm 0.15$ & $* * *$ \\
\hline Duration of short meals (min) & $22 \pm 3.3$ & $22 \pm 1.2$ & & $25 \pm 4.0$ & $21 \pm 1.3$ & & $24 \pm 2.6$ & $22 \pm 0.9$ & \\
\hline Number of long meals ${ }^{1}$ & $0.2 \pm 0.08$ & 0.0 & & $0.1 \pm 0.04$ & $0.2 \pm 0.09$ & & $0.1 \pm 0.05$ & $0.1 \pm 0.05$ & \\
\hline Duration of long meals ( $\mathrm{min}$ ) & $75 \pm 11.2$ & - & & $86 \pm 7.7$ & $75 \pm 2.2$ & & $76 \pm 10.0$ & $67 \pm 4.1$ & \\
\hline
\end{tabular}

${ }^{1}$ Short meal: $<60 \mathrm{~min}$; long meal: $>=60 \mathrm{~min}$

${ }^{2}$ Number of cows eating the same time. 
but the difference was not significant. The average daily rate of eating of $8 \mathrm{~g} / \mathrm{min}$ was very similar between Hom and Het groups for the two types of cows.

No effect of treatment (Hom vs. Het) was detected for the number of long meals, whatever the daily period and the physiological state of the cows. However, the cows had smaller meals in the Het groups: 11.1 vs. 9.0 for dry cows and 12.4 vs. 10.6 for lactating cows. The difference was significant for the daily period (2 more small meals), and the total number of daily meals was 9.8 and 11.8 , in the Hom and Het groups, respectively.

The average values of synchronisation of eating activity differed according to the physiological state but not according to the composition of the groups: 1.63 and 1.82 $(P<0.001)$ vs. 1.70 and $1.81(P<0.01)$, respectively for dry and lactating cows in Hom vs. Het groups. These values are the averages for the 3 cows in each physiological state, without considering their counterparts. The values of synchronisation for the 6 cows in the Het groups were 2.80: 2.86 and 2.75 for dry and lactating cows respectively, when their respective counterparts were considered. In this case, the difference between the physiological states was not significant. Whatever the situation, fewer than half of the cows in the group ate at the same time.

The daily pattern of eating (Fig. 1) can be described similarly for the two treatments and no significant statistical differences were detected at any time of the day between the two distributions. However, some tendencies can be underlined: there were two long bouts of eating activity following distribution of hay for about $2 \mathrm{~h}$ each. The time spent eating ranged from 25 to $30 \mathrm{~min} / \mathrm{h}$ in the two treatments. Between these two main bouts, the time spent eating stayed at a higher level than the daily average (13 $\mathrm{min} / \mathrm{h})$. During this period, the cows in the Het groups tended to eat for less time than the others: 20 min less globally from 13.00 to 19.00 hours. From 20.00 to 10.00 hours, the time spent eating was nearly always under $10 \mathrm{~min} / \mathrm{h}$, except for cows in the Het groups, which had higher eating activities than the others around midnight: 15 to $20 \mathrm{~min} / \mathrm{h}$ spent eating from 22.00 to 2.00 hours. This seems to compensate for the shorter time spent eating after the distribution of hay for these cows. In Figure 2 daily time of eating is represented for dry and lactating cows in Hom and Het groups, confirming that the difference in the pattern of daily eating was significant only for lactating cows. Lactating cows had a higher eating activity from

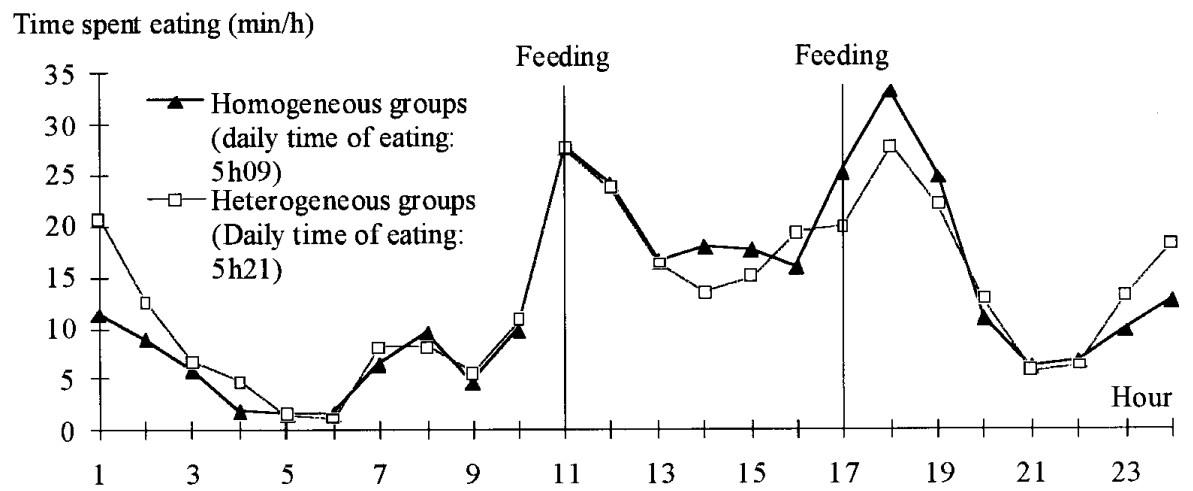

Figure 1. Time spent eating by Charolais cows in groups made up of cows with different or similar physiological states. 


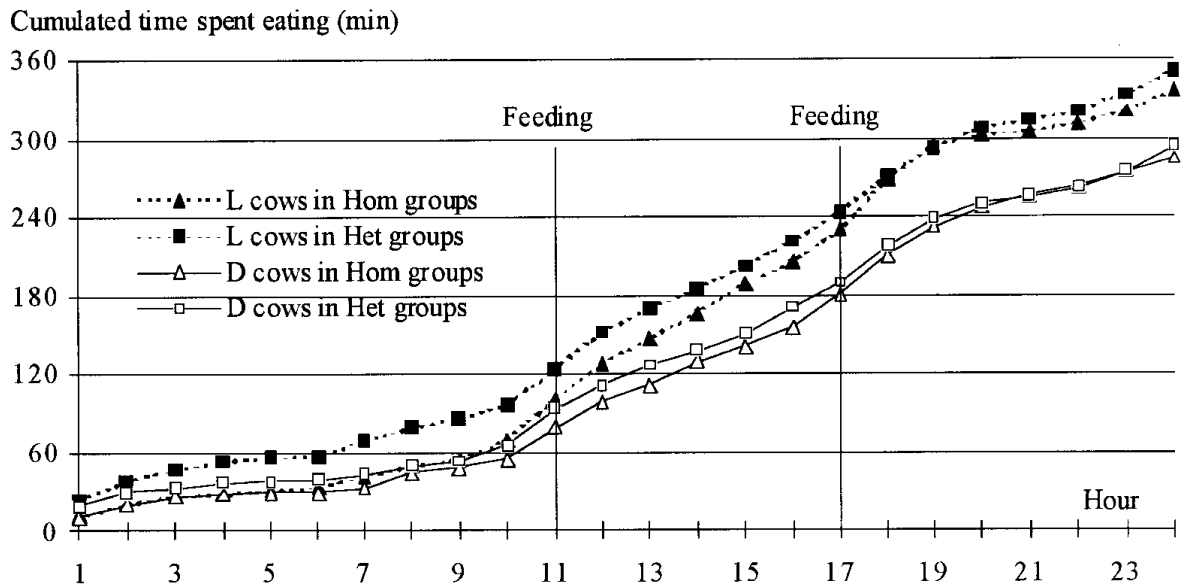

Figure 2. Cumulated time spent eating by dry and lactating Charolais cows in groups made up of cows with different (Het) or similar (Hom) physiological states.

midnight to the first feeding when they were kept with dry cows (Het): at 10.00 hours, they had already spent 2 h eating vs. 1 h 30 when they were in a separate group (Hom). In this latter case and during the same period, the time spent eating by lactating cows was similar to that spent by dry cows. After the first distribution of hay, the specific eating behaviour thus concerned lactating cows in Hom groups which increased their time spent eating faster than in the three other situations (dry for both types of groups and lactating for Het groups). At 16.00 hours (second distribution), the time spent eating was similar for the two treatments but differed for physiological states: $3 \mathrm{~h}$ and $4 \mathrm{~h}$ respectively for dry and lactating cows. The evolution of the curves was thus similar irrespective of the treatment and the physiological state until midnight.

\subsection{Individual variability in differences between treatments}

A multivariate analysis (PCA and cluster analysis) was performed using 5 variables representing the differences between Hom and Het treatments for feeding behaviour (intake, time of eating, number of long and short meals, synchronisation of eating activity). Four groups (G1, G2, G3 and G4) were distinguished by the analysis, with $2,3,3$ and 4 cows respectively. The proportions of the total variation accounted for by the first, second and third principal components (PCA) were 45, 26 and $20 \%$. The first component discriminates cows according to the difference between Hom and Het for the number of long meals and the daily time of eating. The second component discriminates cows according to the difference between Hom and Het for the synchronisation of eating and the daily intake level. The third component discriminates cows for the number of short meals. Therefore, the individual modification of intake was not the first discriminating variable, indicating that all cows did not modify their feeding behaviour in the same way and that there are different individual adaptive strategies within the group.

The groups can be described according to some characteristics of the cows as follows (Tab. IV): G1 $(n=2)$ : cows from G1 strongly fractionised their feeding activity when mixed with lactating cows: 3.3 more daily short meals and 0.4 less daily long 
Table IV. Description of the clusters (G1 to G4) corresponding to different individual modifications of the feeding behaviour of group-fed Charolais cows, according to the homogeneity of the within-group physiological states.

\begin{tabular}{|c|c|c|c|c|}
\hline Group (cluster) & 1 & 2 & 3 & 4 \\
\hline Number of cows & 2 & 3 & 3 & 4 \\
\hline Number of lactating cows & 0 & 1 & 2 & 3 \\
\hline \multicolumn{5}{|c|}{ Variation of parameters of feeding behaviour ${ }^{l}$} \\
\hline$\Delta$ Intake level (kg DM/day) & -0.20 & 0.39 & -0.56 & -0.34 \\
\hline$\Delta$ Intake duration (min/day) & 0 & -10 & 1 & -30 \\
\hline$\Delta$ Synchronisation of eating ${ }^{2}$ & -0.16 & 0.07 & 0.00 & 0.06 \\
\hline$\Delta$ Number of short meals (/day) ${ }^{3}$ & -3.3 & -1.9 & -1.4 & -2.6 \\
\hline$\Delta$ Number of long meals(/day $)^{3}$ & 0.4 & 0.2 & 0.5 & 0.1 \\
\hline \multicolumn{5}{|c|}{ Values of feeding parameters in the homogeneous group } \\
\hline Intake level (kg DM/day) & 14.1 & 15.5 & 14.8 & 14.9 \\
\hline Intake duration (min/day) & 297 & 286 & 341 & 309 \\
\hline Rate of intake (g DM/min) & 49 & 55 & 44 & 49 \\
\hline Synchronisation of eating $^{2}$ & 1.58 & 1.75 & 1.69 & 1.81 \\
\hline \multicolumn{5}{|l|}{ Characteristics of the cows } \\
\hline Body weight (kg) & 741 & 803 & 724 & 695 \\
\hline Height at withers $(\mathrm{cm})$ & 128 & 130 & 133 & 129 \\
\hline Body condition score (0 to 5 ) & 3.4 & 2.9 & 2.2 & 2.1 \\
\hline Social rank (1 to 3 ) & 2.5 & 1.7 & 2.0 & 2.0 \\
\hline
\end{tabular}

${ }^{1}$ Value in heterogeneous group minus value in homogeneous group.

${ }^{2}$ Within-physiological state values, measured in homogeneous groups ( 3 cows); number of cows eating at the same time.

${ }^{3}$ In heterogeneous group (6 cows).

meals in Het groups. These cows were fat dry submissive cows and had low intake levels.

$\mathrm{G} 2(n=3)$ : cows from $\mathrm{G} 2$ decreased their intake in Het groups: $400 \mathrm{~g} /$ day less DM. They were distinguished mostly by a high intake rate due to a low daily time of eating (4 h 46). They were heavy (> $800 \mathrm{~kg}$ ), dominant, the lactating cow of the group had a low milk yield.

G3 $(n=3)$ : cows from G3 increased their intake level in Het groups: $600 \mathrm{~g}$ /day more $\mathrm{DM}$, despite a decrease in the number of daily long meals. They were leaner than the others and were distinguished by a low rate of intake, due to a high daily time of eating (5 h 41).

G4 ( $n=4)$ : cows from G4 increased their daily time of eating (+30 min/day), number of short meals (+2.6/day) and intake level $(+340 \mathrm{~g} /$ day DM) in Het groups. These cows were light $(<700 \mathrm{~kg})$, but had a high intake level (15 kg/day DM) associated with a high milk yield for the 3 lactating cows $(8.4 \mathrm{~kg} /$ day $)$.

The composition of the four groups of cows was primarily based on modifications in the daily time of eating, which had a high contribution to the first component of the PCA. The differences for each group can be analysed precisely since data are available every hour. Most of the differences between Hom and Het treatments occurred from the second distribution of hay to 02.00 hours in the night (Fig. 3a). During this period, the differences of time spent eating between Hom and Het alternate from positive to negative values around $10 \mathrm{~min} / \mathrm{h}$, compared to 


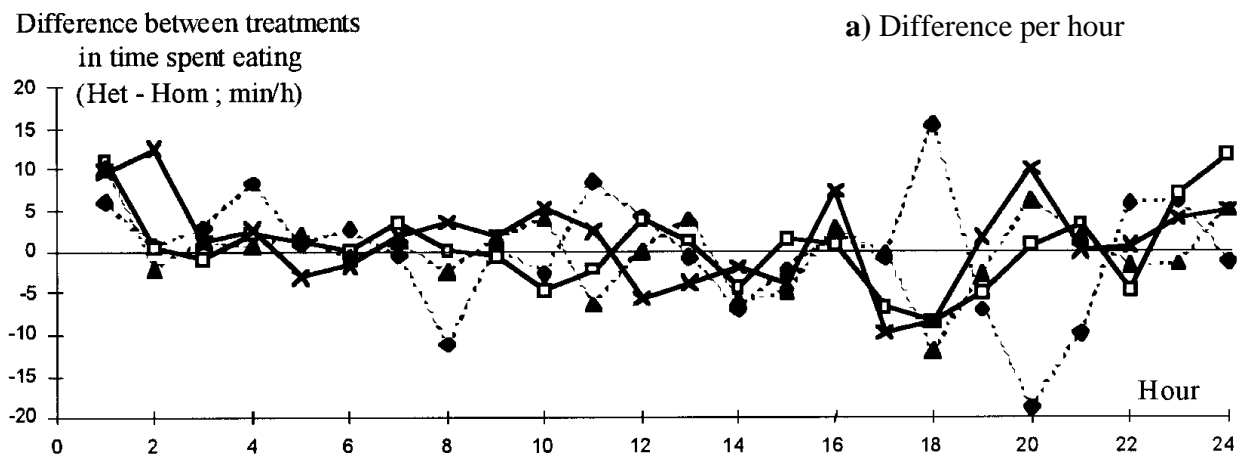

\section{$\begin{array}{ll}\text { Cumulated difference between } & \text { b) Cumulated difference }\end{array}$}

treatments in time spent eating

(Het -Hom ; $\min / \mathrm{h}$ )

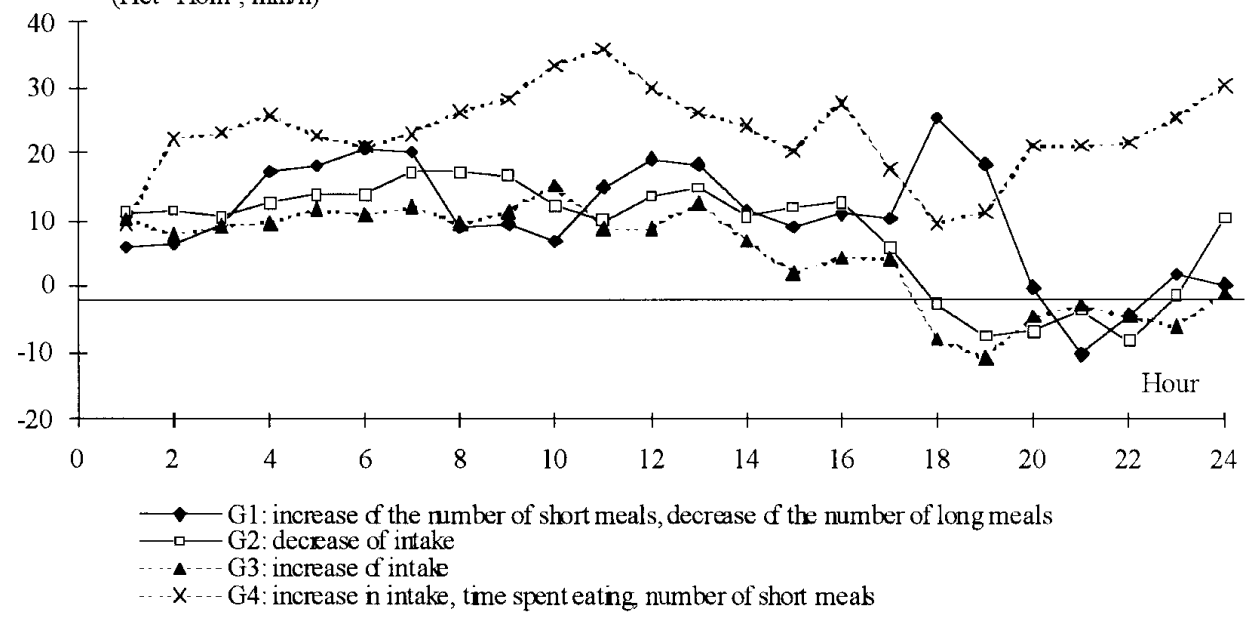

Figure 3. Difference in time spent eating throughout the day for loose-housed Charolais cows according to the group to which they belong (4 groups (G1 to G4) were obtained by clustering the cows according to the differences obtained in individual intake and feeding behaviour when dry and lactating cows were managed together (Het) or separately (Hom)).

$5 \mathrm{~min} / \mathrm{h}$ during the rest of the daily period. Cows in the Het group ate less just after the second distribution of hay, during 2 hours, except for cows from G1. Besides, the behaviour of the cows from G1 was particular since the differences tended to be opposed to those of the cows from other groups. The cumulated values throughout the day show some specific profiles for cows from G1 and G4 (Fig. 3b). The curve for the former is very irregular when the curve for the latter is always positive. The curves corresponding to cows from G2 and G3 are quite parallel. For all groups, the cumulative values are positive from midnight to the second distribution of hay. So, firstly the same daily values could be obtained by different ways and secondly, the modifications of the cows' behaviour were not regularly spread over the daily period. In addition, the distribution of hay, especially in the afternoon, seemed to be a major factor 
inducing the expression of the differences measured between the two treatments, despite the fact that cows were fed ad libitum (some hay was always available in the mangers).

Finally, dry cows were mostly spread into groups 1 and 2 (4 out of 5) and lactating cows in groups 3 and 4 (5 out of 7). Dry cows were distinguished by their body weight (light and heavy cows in groups 1 and 2, respectively), those from group 2 being higher ranked (dominant). The lactating cows were not easily distinguished according to their body weight, milk yield, body reserves or social rank. The social rank seemed to play a role only for cows having low requirements (G1 and G2): submissive cows (G1) markedly fractionised their feeding activities when mixed with cows having high nutritional requirements. For lactating cows, the milk yield seemed to be the first factor inducing some modifications in feeding behaviour in heterogeneous groups and the fractionising was greater for high producing small cows (so, the more "efficient": G4).

\section{DISCUSSION}

In this study the group size was assumed to have no effect on intake level and feeding behaviour, because there was no competition for feed in the group: hay was given ad libitum and manger space was sufficient to allow all the cows to feed at once [2, 31]. In previous trials, with the same conditions of feeding, but with 6 cows in similar physiological states in the same group, the synchronisation of eating activity was comparable, with half the cows eating at the same time on the average [16]. When there is some competition for feeding, group size (that is competition level) has significant effects, and several authors have compared the performance and behaviour of animals according to the number of animals per feeder: for example with growing pigs [31], beef cattle $[5,11]$ and dairy cattle $[9,12]$. The feeder tends to be used continuously $[11,31]$ and the number of meals tends to increase as the group size increases [5]. Friend and Polan [9] found a decrease in intake level and time of eating of a complete ration only for a trough length under $20 \mathrm{~cm}$ per dairy cow.

In many studies, the feeding behaviour was monitored for only one day, as reported by Dado and Allen [7]. These authors suggest using 12 cows measured for 5 days in a Latin square design to obtain sufficient statistical power and sensitivity in such experiments. The present study involved 12 cows, with continuous monitoring of individual feeding behaviour for 14 weeks. The use of individual cow-day data in each group was determined by the objective of the study, where the social interaction with other animals in the group, according to their physiological state, was considered as the treatment.

In the environment designed to keep dry and lactating cows separate (fence partition), the cows could see, hear and smell the cows in the adjacent pen. The social facilitation effect could therefore have been significant between the two groups even if the cows were not "physically" together. This possible social facilitation through the fence should be quantified.

Values of intake level obtained in the present study (14.6 and $15.3 \mathrm{~kg} \mathrm{DM} / \mathrm{cow} /$ day respectively for dry cows $(782 \mathrm{~kg})$ and lactating cows $(694 \mathrm{~kg})$ ) meet French recommendations for the Charolais breed [24]. They correspond to the range given by Petit et al. [25]: 1.06 to $2.17 \mathrm{~kg}$ DM per $100 \mathrm{~kg}$ LW during pregnancy and 1.42 to $2.30 \mathrm{~kg}$ DM per $100 \mathrm{~kg} \mathrm{LW}$ during lactation. The high rate of intake of dry cows in the present study can be explained by their high body weight [4, 18]. Lactating cows achieved greater dry matter intake by increasing daily feeding time but not the number of meals. This is in agreement with the results reported by Dado and Allen [7]. 
The differences detected when dry and lactating cows were mixed in the same group were firstly the greater number of short meals for both types of cows (9.0 vs. 11.1 for dry cows and 10.6 vs. 12.4 for lactating cows, respectively in Hom and Het groups). In a previous trial, we obtained similar values for loose-housed Charolais cows: 10.3 and 12.5 daily meals, respectively for dry and lactating cows [13]. The differences detected were secondly, the greater eating activity of lactating cows at night and the fractionisation of the eating activity, especially for submissive dry cows and high producing lactating cows, as if the treatment had induced some competition for food $[9,10,20]$. These results did not allow us to validate our initial hypothesis assuming that dry cows kept in a group with lactating cows synchronise their eating activity with the latter and tend to eat more and for a longer time than when they are kept in a specific group (homogeneous according to the physiological state) $[26,27]$.

\section{CONCLUSION, IMPLICATIONS}

Mixing dry and lactating cows in the same group when fed a good hay ad libitum had little effect on average intake and feeding behaviour: more short meals in mixed groups and more feeding at night for lactating cows. The individual variability of the effect of the treatment was explained by the social rank among cows with low requirements (that is dry cows) and by the milk yield among cows with high requirements (that is lactating cows). Net energy requirements of the latter were twice those of the former: respectively 9.3 and 4.5 UFL/day/cow. These requirement levels can be considered low and closed, compared with those of dairy animals during lactation (20 to 25 UFL/day in early lactation and 5 to 10 during the dry period). Thus the withingroup potential of variability of individual requirements for beef cows is relatively limited and so, individual performance (approached here by intake and feeding behaviour) may not be affected in a noncompetitive situation. Further investigations are in progress to ascertain the effect of competition for feeding on intake level and feeding behaviour of cows in homogeneous and heterogeneous groups.

\section{ACKNOWLEDGEMENTS}

We thank all the technical staff of Laqueuille for their help with feeding and handling the experimental animals. We thank Christine Durier, from Inra's biometry department, for her assistance in statistical analysis

\section{REFERENCES}

[1] Agabriel J., Giraud J.M., Petit M., Détermination et utilisation de la note d'état d'engraissement en élevage allaitant, Bull. Tech. C. R. Z. V. Theix 66 (1986) 43-50.

[2] Albright J.L., Arave C.W. (Eds.), The Behaviour of cattle, CAB International, Oxon, New York, 1997.

[3] Beauchemin K.A., Zelin S., Genner D., An automatic monitoring system for quantification of eating and rumination activities of dairy cattle housed in stall, J. Dairy Sci. 72 (1989) 2288-2300.

[4] Campling R.C., Morgan C.A., Eating behaviour of housed dairy cows, A review, Dairy Sci. Abstr. 43 (1981) 57-63.

[5] Corkum M.J., Bate L.A., Tennessen T., Lirette A., Consequences of reduction of number of individual feeders on feeding behaviour and stress level of feedlot steers, Appl. Anim. Behav. Sci. 41 (1994) 27-35.

[6] Dado R.G., Allen M.S., Relationships among feeding variables for lactating cows offered a common diet, J. Dairy Sci. 75 (1992) 294.

[7] Dado R.G., Allen M.S., Variation in and relationships among feeding, chewing and drinking variables for lactating cows, J. Dairy Sci. 77 (1994) 132-144.

[8] Forbes J.M., Jackson D.A., Johnson D.L., Stockill P., Hoyle B.S., A method for the automatic monitoring of feed intake and feeding behaviour of individual cattle kept in a group, Res. Dev. Agric. 3 (1986) 175-180.

[9] Friend T.H., Polan C.E., Social rank, feeding behavior, and free stall utilization by dairy cattle, J. Dairy Sci. 57 (1974) 1214-1220. 
[10] Friend T.H., Polan C.E., McGilliard M.L., Free stall and feed bunk requirements relative to behavior, production and individual feed intake in dairy cows, J. Dairy Sci. 60 (1977) 108-116.

[11] Gonyou H.W., Stricklin W.R., Eating behaviour of beef cattle groups fed from a single stall or trough, Appl. Anim. Ethol. 7 (1981) 123-133.

[12] Harb M.Y., Reynolds V.S., Campling R.C., Eating behaviour, social dominance and voluntary intake of silage in group-fed milking cattle, Grass Forage Sci. 40 (1985) 113-118.

[13] Ingrand S., Agabriel J., Lassalas J., Individual feeding vs. group feeding for Charolais cows, Renc. Rech. Rum., Paris 4 (1997) 91.

[14] Ingrand S., Vimal T., Fléchet J., Agabriel J., Brun J.P., Lassalas J., Dedieu B., A free access system for the long-term monitoring of individual intake of beef cows kept in a group, in: Gibb M.J. (Ed.), Proceedings of the Ninth European Intake Workshop, IGER, Aberystwyth, United Kingdom, 1998, pp. 17-20.

[15] Ingrand S., Dedieu B., Agabriel J., Critères de constitution des lots de vaches dans des troupeaux bovins allaitants Limousins et Charolais, INRA Prod. Anim. 12 (1999) 61-71.

[16] Ingrand S., Agabriel J., Dedieu B., Lassalas J., How group feeding influences intake level of hay and feeding behaviour of beef cows, Ann. Zootech. 6 (1999), in press.

[17] Jarrige R. (Ed.), Alimentation des ovins, bovins et caprins, INRA, Paris, 1988.

[18] Jarrige R., Dulphy J.P., Faverdin P., Baumont R., Demarquilly C., Activités d'ingestion et de rumination, in: Jarrige R., Ruckebusch Y., Demarquilly C., Farce M.H., Journet M. (Eds.), Domestic Ruminant Nutrition, Ingestion and digestion, Paris, 1995, pp. 123-181.

[19] Journet M., Rémond B., Physiological factors affecting the voluntary intake of feed by cows: a review, Livest. Prod. Sci. 3 (1976) 129-146.

[20] Leaver J.D., Yarrow N.H., A note on the effect of social rank on the feeding behaviour of young cattle on self-feed maize silage, Anim. Prod. 30 (1980) 303-306.
[21] Lebeaux M.O., ADDAD : Guide de l'utilisateur, Association pour le Développement et la Diffusion de l'Analyse des Données, Paris, 1985.

[22] Le Neindre P., Observations sur l'estimation de la production laitière des vaches allaitantes par la pesée du veau avant et après la tétée, Ann. Zootech. 22 (1973) 413-422.

[23] Little W., Manston R., Wilkinson J.I.D., Tarrant M.E., Some factors related to the voluntary intake of silage by individual dairy cows housed as a group during two winter-feeding periods, Anim. Prod. 53 (1991) 19-25.

[24] Petit M., Agabriel J., Beef cows, in: Jarrige R. (Ed.), Ruminant Nutrition: Recommended allowances and feed tables, John Libbey Eurotext, Paris, 1989, pp. 93-107.

[25] Petit M., Jarrige R., Russel A.J.F., Wright I.A. Feeding and nutrition of the suckler cow, in: Jarrige R., Béranger C. (Eds.), Beef Cattle Production, Elsevier, Amsterdam, 1992, pp. 191-208.

[26] Rook A.J., Penning P.D., Synchronisation of eating, ruminating and idling activity by grazing sheep, Appl. Anim. Behav. Sci. 32 (1991) 157-166.

[27] Rook A.J., Huckle C.A., Synchronisation of ingestive behaviour by grazing dairy cows, Anim. Sci. 60 (1995) 25-30.

[28] Statistical Analysis System Institute, SAS/STAT User's guide release 6.03 edition, SAS Institute Inc. Cary, NC, 1988.

[29] Szúcs E., Ács I., Ugry K., Csiba A., Effect of group size on the performance and comfort behaviour of dairy cows of high genetic potential, in: Proc. of the 42th Annual Meeting of the EAAP, Berlin, 1992, Vol. 1, p. 509.

[30] Veissier I., Le Neindre P., Trillat G., The use of circadian behaviour to measure adaptation of calves to changes in their environment, Appl. Anim. Behav. Sci. 22 (1989) 1-12.

[31] Walker N., The effects on performance of behaviour of number of growing pigs per monoplace feeder, Anim. Feed Sci. Technol. 35 (1991) 3-13. 